\title{
Does Quality of Corporate Governance Moderate the Relationship between Corporate Social Responsibility and Stock Price Crash Exposure
}

\author{
MUHAMMAD BILAL ${ }^{1}$, SARFRAZ HUSSAIN ${ }^{2}$, MUHAMMAD RAFIQ ${ }^{3}$, NISAR AHMAD $^{4}$, \\ ABDUL QUDDUS 5 , TIEN PHAT PHAM ${ }^{6}$ \\ ${ }^{1}$ AIR UNIVERSITY ISLAMABAD (Multan Campus) Multan, PAKISTAN \\ Government College Civil lines Multan, Email: mbilal77kg@gmail.com \\ 2UNIVERSITI TEKNOLOGI MALAYSIA, Kuala Lumpur, MALAYSIA \\ GOVT. IMAMIA COLLEGE SAHIWAL, PAKISTAN, Email: mianfraz1@gmail.com \\ ${ }^{3}$ UNIVERSITI TEKNOLOGI MALAYSIA, Kuala Lumpur, MALAYSIA \\ PRINCE MOHAMMAD BIN FAHD UNIVERSITY, Akhobar, Dammam, SAUDI ARABIA, Email: mrafiq@pmu.edu.sa \\ ${ }^{4}$ Assistant Professor Hailey College of Commerce, UNIVERSITY OF THE PUNJAB LAHORE, PAKISTAN. \\ Email: nisar@hcc.edu.pk \\ ${ }^{5}$ TOMAS BATA UNIVERSITY IN ZLIN, CZECH REPUBLIC, Email: quddus@utb.cZ \\ ${ }^{6}$ TOMAS BATA UNIVERSITY IN ZLIN, CZECH REPUBLIC \\ SCHOOL OF ECONOMICS, CAN THO UNIVERSITY, VIETNAM, Email: phamphattien@gmail.com
}

\begin{abstract}
The relationship between corporate social responsibility and vulnerability to stock market crashes and how this relationship is moderated by the norm of corporate governance was empirically explored in this research article. This study used a panel data analysis using a group of 58 companies selected during the years 2009-2018 from operating in various industries hawking their stock on the Pakistan Stock Exchange (PSX) to investigate this interaction effect. To quantify the company's share price probability of a crash, an inverse restrictive skewness (NCSKEW) of returns and bottom-to-up variance (DUVOL) spread has been used as a proxy. The results of this research suggest that the risk of a share price slump is adversely and significantly linked to CSR. Consistency structures of governance mechanisms (size of the board, percentage of autonomous directors on board, concentration of ownership, percentage of executive directors onboard) have a substantial moderating impact on the risk of a fall of the share price.
\end{abstract}

Keywords: Stock Price Crash-risk; Corporate Governance Structure; Agency theory; Signaling theory Corporate Social Responsibility.

JEL Classification: M10, M14, G34

Received: June 22, 2021

Accepted: September 18, 2021 


\title{
¿Modera la Calidad del Gobierno Corporativo la Relación entre la Responsabilidad Social de las Empresas y la Exposición a la Caída del Precio de las Acciones?
}

\author{
MUHAMMAD BILAL ${ }^{1}$, SARFRAZ HUSSAIN ${ }^{2}$, MUHAMMAD RAFIQ ${ }^{3}$, NISAR AHMAD $^{4}$, \\ ABDUL QUDDUS ${ }^{5}$, TIEN PHAT PHAM ${ }^{6}$ \\ ${ }^{1}$ AIR UNIVERSITY ISLAMABAD (Multan Campus) Multan, PAKISTAN \\ Government College Civil lines Multan, Email: mbilal77kg@gmail.com \\ 2UNIVERSITI TEKNOLOGI MALAYSIA, Kuala Lumpur, MALAYSIA \\ GOVT. IMAMIA COLLEGE SAHIWAL, PAKISTAN, Email: mianfraz1@gmail.com \\ ${ }^{3}$ UNIVERSITI TEKNOLOGI MALAYSIA, Kuala Lumpur, MALAYSIA \\ PRINCE MOHAMMAD BIN FAHD UNIVERSITY, Akhobar, Dammam, SAUDI ARABIA, Email: mrafiq@pmu.edu.sa \\ ${ }^{4}$ Assistant Professor Hailey College of Commerce, UNIVERSITY OF THE PUNJAB LAHORE, PAKISTAN. \\ Email: nisar@hcc.edu.pk \\ ${ }^{5}$ TOMAS BATA UNIVERSITY IN ZLIN, CZECH REPUBLIC, Email: quddus@utb.cz \\ ${ }^{6}$ TOMAS BATA UNIVERSITY IN ZLIN, CZECH REPUBLIC \\ SCHOOL OF ECONOMICS, CAN THO UNIVERSITY, VIETNAM, Email: phamphattien@gmail.com
}

\begin{abstract}
RESUMEN
En este artículo de investigación se exploró empíricamente la relación entre la responsabilidad social de las empresas y la vulnerabilidad a las caídas de la bolsa y cómo esta relación está moderada por la norma de gobierno corporativo. En este estudio se utilizó un análisis de datos de panel con un grupo de 58 empresas seleccionadas durante los años 2009-2018 que operan en diversos sectores y que cotizan en la Bolsa de Pakistán (PSX) para investigar este efecto de interacción. Para cuantificar la probabilidad de que el precio de las acciones de la empresa se estrelle, se ha utilizado una asimetría restrictiva inversa (NCSKEW) de los rendimientos y un diferencial de varianza de abajo hacia arriba (DUVOL) como proxy. Los resultados de esta investigación sugieren que el riesgo de caída del precio de las acciones está vinculado de forma negativa y significativa a la RSC. Las estructuras de consistencia de los mecanismos de gobierno (tamaño del consejo, porcentaje de consejeros autónomos en el consejo, concentración de la propiedad, porcentaje de consejeros ejecutivos en el consejo) tienen un impacto moderador sustancial en el riesgo de caída del precio de las acciones.
\end{abstract}

Palabras clave: Riesgo de caída del precio de las acciones; Estructura de gobierno corporativo; Teoría de la agencia; Teoría de la señalización de la responsabilidad social corporativa.

Clasificación JEL: M10, M14, G34

Recibido: 22 de Junio de 2021

Aceptado: 18 de Septiembre de 2021 


\section{Introduction}

Since businesses are forced to report both qualitative and quantitative market threats, such as the vulnerability of foreign currency exchange rates, the exposure of interest rates, the danger of changes in commodity or stock prices. At the same time, the data quality of the disclosure depends on the discretion of the managers. There is a perception that disclosure of market risk offers only boilerplate information that does not help understand the risk exposure of the business. The most important corporate abuse scam uncovered in the past is the Enron scandal in which management did off-balance singe intention asset to mask assets missing value and told potential investors that the company would continue to grow in future stock values while covertly starting to unload its shares. The Enron scam is perhaps one of the most historical instances that highlight the severity of the stock market collapse and prompted the Sarbanes-Oxley Act 2002 to be enforced, which mandates executive management to certify the honesty of the corporation's financial statements and to enhance fines and strictness for deceitful behavior. In addition to identifying an important positive correlation between asymmetric information and the crash risk, the researchers Kim et al. (2011-a) have also established the effect of the asymmetry of information on a company's stock and on the stock market as a whole. Several previous studies on collapse risk have focused on its different factors, such as religious impact group preferences (Li et al., 2017; Kim et al., 2011).

Bearing in mind the corporate scandals and the financial crisis, politicians, analysts, and researchers have begun to investigate the possibility of the share price collision phenomenon. A restricted lopsidedness of the return division that measures variations in a threat related to the price of shares is the stock price crash risk as described in the available information (Kim et Al., 2014). In the field of crash risk analysis, it is believed that when investors realize that an asset value has been overestimated, there is a possibility of a capital value dispute arising. Jin and Myers (2006) believed that both managers and shareholders have asymmetric information followed by the self-interest of managers; thus, capital values are likely to clash. Research by Hutton et al. (2009) states that a company's return mistiness is comparable to the higher risk of share value conflict; they also reported that managers mask bad news by the poorer quality of the accruals listed in the earnings of the company, resulting in a stock price crash. Kim et al. (2011) investigated the affiliation concerning the propensity of managers to hold the wrong report and reassure crash risk through equity-based compensation.

Kim et al. (2016) defined the phenomenon of stock price crashes based on a psychological concept and stated that the overconfidence of the CEO is significantly positively related to the company-specific likelihood of a stock price crash. Taylor \& Gollwitzer (1995) argued that because of past confidence in their capacities, the negative feedback on ongoing ventures is not rationally processed by overconfident CEOs, and they conclude that they are able enough to cope with the impacts of such schemes by misjudging their likelihood of failure. They overestimate their potential and assume that in the long run, working with the negative net present value, the firm value will be strengthened by them. This over-confidence bias causes CEOs to gather bad news about these projects. According to Kim et al. (2016), when added, the unfortunate performance of the overconfident CEOs crosses a threshold stage; the bad news is revealed when the share price fall of the company is already provided.

Baker et al. (2016) suggested that the volatility in the stock market is concerned with the vagueness of macro-economic policies such as regulatory policies, fiscal and monetary policies due to shifts in economic policy. The link between stock values and financial policy ambiguity has been discussed in a plethora of research studies. In the event of policy instability, market prices are empirically checked to be more volatile. According to Li (2017), uncertainty primes an equity premium in an economic strategy. Recently, Lam et al. (2018) showed that policy uncertainty is reliably priced in return on equity across 49 countries. Many studies have revealed the unique factors of the business causing the risk of the share price failure, but few investigations have analyzed the influences that affect the risk of the crash in the stock price. The relationship between staff wellbeing and the risk of a fall in stock prices has also been explored by researchers. 
Ben et al. (2018) suggest that the probability of a stock price crash decreases due to high-quality employee wellbeing and better-quality working conditions, according to the stakeholder hypothesis, allowing the business to create a favorable reputation. The good image of the company usually means that the stakeholders and shareholders of the company, Brammer, and Pavelin (2006), are persistently committed. In the absence of the good reputation of its employees, Clarkson (1995) makes it very difficult for businesses to achieve higher potential returns or even to thrive. According to Bhana (1997), due to staff strikes, the firm value is decreased, and the risk of employees' strikes is reduced due to employee satisfaction. According to the stakeholder theory study, the stability of the stock price and the probability of an abnormal decline in the share price can be achieved by sophisticated staff handling standards because it helps prevent the expensive boycott of the workers, enhance the shareholder's continued interest, and enhance the company's good reputation on the market. Heinle et al. (2018) say that a company manager might be able to decrease the crash risk of share prices by disclosing more details about the risk regarding future cash flows. In addition, disclosure of such sources of market risk can help minimize the incidence of a stock price collapse, particularly as such disclosures enable investors more honestly predict the variability of the firm's cash flows.

A growing multiple disciplines paper on CSR, its influence on the actions and results of companies is a reaction to the persistence of CSR in action. The associated with corporate social achievement and corporate financial results has been researched in several studies (Kim and Statman, 2012). CSR practices of corporations and the possibility of stock market crash risk for firms operating in developing economies (Chia et al., 2019). Few studies have explored the connection between CSR and the return on capital (El Ghoul et al., 2011; Goss and Roberts, 2011; Dhaliwal et al., 2011). Even then, for companies operating in developing economies such as Pakistan, the effects of CSR on the possibility of a stock price crash have not yet been empirically checked. The relationship between corporate governance and share price crash risk for firms mentioned on the PSX is therefore important to analyze. The investigators have also not yet explored the moderating effect of corporate governance features here between the risk of CSR and the share value collapse threat of Pakistani firms. Therefore, this study is designed to investigate the moderating effect of CSR disclosure on the stock price volatility of listed companies for the period from 2009 to 2018. For investigating the role quality of CG, we emphasized certain corporate governance features such as the size of the board, percentage of autonomous and corporate directors on boards, and institutional ownership.

In Pakistan, the emphasis of earlier research studies remained restricted only to the impact of the social responsibility activities of corporations on their monetary growth. This study is This study adds to the prevalent literature by extending the reach of corporate social responsibility analysis as follows:

First, this study is aimed to investigate the impact of CSR disclosure of companies on the risk of an abnormal decline in the company's share price. Second, almost all research studies have been performed in developed economies on an abnormal plummet in the share price of companies, offering a limited view of the developed market with diverse corporate environments and legal structures. By observing emerging markets, particularly Pakistan, this study contrasts with previous studies. Third, this research study helps to recognize the determinants of the abnormal decline in share prices of a business operating in Pakistan. Fourth, the study finds that managers, investors, and regulators are referred to monitor abnormal market volatility in share prices by investing more in CSR-related activities and improving the corporate governance process. The remaining part of the article is designed as: Section 2 presents literature review \& formulation of hypotheses, and section 3 illustrates the methodology. Empirical findings are described in Section 4, while, conclusion, policy implications, and ideas for future work are proposed in Section 5.

\section{Hypotheses Development}

Literature shows that CSR has two opposing perspectives on its monetary implications; the first is the social effect hypothesis, which notes that the actions of CSR raise the interest of all stakeholders. According to this view, the business increases the confidence of customers through CSR activities, 
strengthens the corporate brand image, creates a positive reputation, generates market competition, and thus enhances the overall perception of all stakeholders. Hategan et al. (2018) discovered that CSR activities raise the confidence of shareholders and have a helpful impact on business productivity, thereby leading to the company's better monetary results. In comparison, if the company fails to fulfill the standards of shareholders and ultimately reduces the company's profitability, distrust is generated in the market (Cornell and Shapiro, 1987). The theory of management balance is the second view of the monetary implications of CSR, which notes that the interests of managers are secured rather than those of shareholders only by CSR practices.

According to the view of the management balance theory, each stakeholder's interest cannot be entirely satisfied with the company, so interest must be measured for each party. If a corporation assumes too much social responsibility, shareholder interests are affected. Ultimately, corporate operations are affected, leading to higher costs and lower financial performance, Friedman (1970). Because of the agency problem, a company's managers benefit from CSR-related advantages, while the company's shareholders pay for the risks and costs of CSR. CSR is therefore regarded as a form of agency expense, as it increases the company's high costs and risk and ultimately weakens the company's competitiveness (Mcwlliams et al., 2006).

A destructive relationship between company societal obligation and the monetary growth of corporations is experienced by some research intellectuals. As reported by Preston et al. (1997), when managers' compensation schemes are related to the company's stock prices and short-term profit, the relationship also evolves between the CSR statements of the companies and their financial results, since managers are pursuing their rewards at the stakeholders' expense. Some academic scholars have also proposed the publication of CSR information to camouflage the effect of some wrongdoing. Therefore, they say that the company's only societal obligation is to use its power to maximize corporate benefit without disrespecting the rules of the business, and they also oppose CSR.

\subsection{CSR-Firm Stock Price Crash Risk Relationship}

Hong and Stein (2003) have shown that the distribution of stock returns is prevalent and has higher frequencies than that of large positive skewed stock returns in stock prices showing large negative skewed stock returns (or the occurrence of a crash). Similarly, several other researchers attempted to predict the causes of the fall in the company's share prices in Hong and Stein's (2003) research studies. The tendency of managers to hide malicious bulletins from stakeholders is one of the key explanations for the risk crash discovered (Hutton et al., 2009). The theory of the Agency notes that an agency problem occurs between a company's management and its stakeholder due to a disagreement between the agent's core goals and that of the principal. The earlier researchers note that because they are worried about job longevity and compensation, executives stockpile the company's malicious bulletin from stockholders (Ball et al., 2009).

Constantly gathered and accumulated bad news upon reaching the point where retention is no longer possible is ten immediately exposed to the public, causing a company's share price to experience crashes. Kim \& Zhang (2013) support the above views by providing that many factors such as uncertain financial statements, tax evasion, and corporate equity-based rewards. It is stated in the stakeholder theory that managers must devise and execute a mechanism that can meet the needs of a certain community, i.e., stakeholders, and satisfy them. In his report, Roberts (1992) notes that corporate social responsibility operations are one of the tasks of the manager to please the stakeholders of the organization and endorse the stakeholder theory. The previous study, however, offers several distinct views relating to the suggestion that corporate social responsibility will discourage or mitigate the actions of managers withstanding bad news and financial statement transparency. Kim et al. (2012) found that publicly responsive businesses are also highly responsible for financial reporting, showing that corporations have a strong ethical responsibility and have a constructive impact on the transparency of corporation statistics. Research by Kim et al. (2014) also noticed that businesses with high-ranking of societal concern had low levels of stockpiles of bad news. The conceptual basis of the bad news stockpile theory of crash risk was given by Jin and Myers (2006), 
supported by arguments that asymmetry of evidence among management and stockholders contributes to the risk of a stock price crash. The theory of bad news hosting behavior advocates that the manager hides bad news for the enjoyment of private benefits such as continuity of jobs and extra perquisites equity inducements from the business (Kim et al., 2011). If the cost of bad news hoarding reaches a certain tolerable cap, executives simultaneously release the accumulated bad news on the market, resulting in an abnormal decline in the stock price, a severe negative out-layer in the distribution of the return.

Similar to the bad news hypothesis, the results of a study conducted by Graham, Harvey, and Rajgopal (2005) suggest that bad news hosting executives are more likely to withhold disclosures compared to managers with good news. Cho et al. (2013) indicate that the incidence of knowledge asymmetry would be reduced by organizations with a high standard of social responsibility. Jensen (2001), however, asserted that the theory of stakeholders does not give executives a strict limit on the degree to which a manager should function to satisfy stakeholders. Friedman (1970) also shares similar concerns, suggesting that corporate social responsibility may be an operational problem that arises within a corporation when used only to please stakeholders. Bradley (2009) argues that immoral corporate practices are covered up by the company's incentive to pursue corporate social responsibility activities.

Kim et al. (2014) also noted that there are concerns that managers can use corporate social responsibility to promote jobs, retain bonuses, and other personal goals in a speculative manner. This argument is also backed by some studies that have to initiate a definite relationship between CSR and benefits executive and tax evasion (Hoi et al., 2013). Kim et al. (2014) claimed that CSR disclosure diminishes the collapse threat of company share price; in addition, while the company had weak company's authority and lower-level management of company's ownership, they reported a positive association between CSR disclosure and the bang menace of the company share price. It is very difficult to determine whether the intention of the organization's management to participate in CSR generally is self-centered or for the benefit of society. Chih et al. (2014) argued that the practice of the socially responsible activities of the organization is camouflaged as an instrument for raising their goodwill and hence their interest in the company.

Management will embrace social transparency strategies to conceal the wrongdoing of the company. In support of this hypothesis, evidence from observational research shows that corporate social responsibility practices are favorably related to capital structure (Prior et al., 2008). For the period 2006-2013, Lu and Nakajima also discussed the link between corporate social responsibility and the crash risk of companies in Japan. (Year 2014). They claimed that the governance system and corporate governance scheme of the Company in Japan would not affect the reduction of the share price crash risk of the company. Based on theoretically and empirically studies on the relationship in the sense of corporate social responsibility and share price crash risk, the investigator intended to examine the effect of the disclosure of share price. Depending on the above rationale, the theoretical study, and the results of previous studies, the hypothesis of our study would be that.

$H a_{1}$ : There is a major adverse correlation between CSR and the company listed on the PSX share price collapse disclosure.

\subsection{Corporate governance quality relationship with share price collapse risk.}

The term corporate governance, as argued by Blair (1995), is generally applicable to the construction and functions of a board of directors in its narrow intellect and is very popular among some research specialists and mentors of organizations. Donaldson (1990) describes firm control as a process by which the board of directors monitors the organization's administrators, officials, workers and establishes compensation programs and other monitoring schemes. The Corporate Governance system is considered as the essential composed of laws, procedures. It primarily involves sharing the desires of an organization's directors, such as shareholders, top leadership, finance suppliers, clients, the administration, and the community in which a corporation holds. 
The effective governance frameworks of the corporation would prevent opportunistic management acts to diminish the possibility of a share value collapse risk, as stated in the previous research literature (An \& Zhang, 2013). The successful control mechanism of businesses serves as a real device to mitigate the clever actions of executive managers, enhance the value of business knowledge, and improve a company's value (Alkurdi et al., 2019). An efficient model of the company's governance in the form of a board of directors, as elaborated by Matten \& Crane (2005), increases impartiality and eliminates agency disputes between management and the company's various stakeholders. The position of the board of directors is significant and contributes to the effective governance of the business in controlling the managers.

In addition, the role of independent directors is to ensure that all monetary decisions made by executive management are in line with shareholders' best interests and that the results associated with these financial decisions are not skewed toward any group of stakeholders (Donaldson \& Preston) (1995). To turn managers' attention to the strategic value development of businesses, the board of directors is expected to provide their managers with acceptable motives. In this respect, the introduction of CSR principles into the company's incentive scheme is a recent trend in the company's governance system. This has yet to be studied empirically as to either the use of the CSR principles in the management incentive framework serves as an efficient governance mechanism or not because the existing literature indicates that such corporate governance mechanisms are unproductive because they lack material evidence and are purely ceremonial (Westphal and Zajac, 1995).

Rewards depending on CSR criteria may also consist of only an extremely little part of the total reward paid by a manager, which would be too gradual for leadership rewards to be successfully formed. In several earlier research studies in the context of emerging economies, the experimental value between company governance and company disclosure of CSR was addressed. Several studies have reported the significant role of a board in issues related to CSR (Muttakin et al . , 2015). However, there is still fairly insufficient experimental proof exploring the association between CSR disclosures and the different characteristics of the board (Hoang et al., 2018). Through board members, a small number of individuals (directors) control the large companies; thus, concerns regarding corporate governance are critical because senior management may take advantage of the company earnings for any related benefit of their own at the cost of the other stakeholder interest. The declaration of earnings manipulation techniques ultimately helps stakeholders to highlight a call for executives to observe certain manipulative behaviors.

That is why, in business and economics today, the mechanism of firm governance has gained so much popularity and significance. As argued in previous literature, strong corporate governance helps to restrict management's biased and unreasonable decision-making (Healy et al., 1999). It is, for instance, accomplished by investment discipline (Masulis et al., 2007), avoidance of manipulation of the yield (Xie et al., 2003), sanitization of the knowledge environment (Armstrong et al., 2012). The above results advocate that opportunistic management activity is minimized through a good governance paradigm; thus, it is also related to company-specific lower share value collapses. In the sense of business governance, the possibility of a CSR disclosure may even use it as an indicator of stability or simply stated that a lower possibility of a share value collapse possibility means a higher degree of the business's sustainability purpose.

The researcher intended to investigate the effect of corporate governance qualities of companies on their share price crash risk in Pakistan, based on theoretical and empirical studies concerning the relationship in the form of corporate governance and the share price chance of a crash. The hypothesis of our research is that, based on the above reasoning, the theoretical analysis, and the findings of previous research.

$H_{a 2}$; There is a significant and inverse relationship between company governance quality and the share price Chance of Crash of Pakistani listed firms. 


\subsection{Interactive Impact of CSR and CG Quality}

The prior literature on Organizational governance's moderating effect on the likelihood of a stock price crash indicates two opposing hypotheses. The literature advocates that successful monitoring of the managers involved in various CSR activities mitigates the corporation's chance of a share price collapse. The corporate governance process and successful internal and external management supervision can have different impacts on the relationship between CSR activities and the possibility of a stock price crash for companies. For example, as the literature states, through the successful monitoring of institutional shareholders, it is ensured that CSR activities carried out by the company's managers are for real foundations, rather than a tactic used to mask the managers' wrongdoing. In this way, the negative connection here between the possibility of a share value crash of companies and their CSR operations is reinforced. Also, the firm's dedication towards CSR is more critical to limit earning management in a poor governance system. Bae et al. (2006) note that shares belonging to companies with a good governance system in a stock market display less positive skewness of return distribution relative to those companies with a weak governance structure because the uncertainty of knowledge is reduced by an efficient governance structure.

The businesses with lower institutional shareholdings and a less effective corporate governance scheme, a negative relationship between the corporate social responsibility of the company and its stock price collapse risk are likely to be apparent. In this paper, we used four governance attributes to study the moderating corporate governance between CSR and the possibility of a collapse in the price of company shares. Board size, the proportion of independent and board members on a company's board, and the ownership structure (shareholding percentage of the top 10 shareholders) are these moderating characteristics. The third hypothesis of this research is, therefore.

$H_{a 3}$ : The influence of "corporate social responsibility" on the share price crash risk of the firm is moderated by the firms' corporate governance quality.

For those factors that could affect the explanatory variables, we are using different control factors, supporting Piotroski et al. (2015). Among all other variables in the corporate finance research sector, the size of the organization is a key variable. Firm size has, for the most part, a broad and positive influence. However, in current literature, a log of sales, the market value of equity, and the log of total assets are typically included in various business size metrics (Dang et al., 2018), ROE, and ROA. Other control variables are used. The literature indicates that the performance of the company and the size of the company are positively connected to the CSR disclosures of the company (Li et al., 2018).

\section{Methodology}

Easterby-Smith et al. (2009) argued that certain covertly and explicitly defined logical postulations are the subject of an analysis of the facts. These logical postulations allow researchers to decide on the tool to be used to analyze a specific case. The approach contains the concepts and procedures that researchers adopt to explore research issues and find answers to the Bogdan \& Taylor (1975) problems. Easterby-Smith et al. (2009) also note that research methodology is defined as a combination of different approaches/procedures followed by researchers to examine a specific research issue (Nguyen \& Do, 2020).

The goal of this study is to observe the effect of CSR disclosure on the risk of the stock price crash of the companies listed on the PSX. Since it is understood globally that the release of CSR facts is a socially constructed notion as something important to be identified as CSR depends on the managers' assigned social duties in a particular perspective (Deegan \& Unerman, 2011). The current literature also indicates that Freeman \& Hasnaoui (2011) have communally invented the idea of CSR. It means that the activity of an organization that is being followed at the same time in one location might not be acceptable for another location. Also, previous studies have shown discrepancies between different motherlands in disclosures of CSR (Laan Smith et al., 2005), between different companies in the same state (Huang \& Kung, 2010), and between companies working in the same sector (Hou \& Reber, 2011; Abbas, Nguyen, Yanfu, and Nguyen, 2020).). This chapter aims to introduce the experimental 
framework for statistical testing of the data relevant to this study. The description of relevant data offers an interpretation of the data sources, data samples, and time used for this analysis. The methodology used to assess the statistical effect of various variables used in this study is also described in this chapter (Dao, Loc, Nguyen, Hang, and Do, 2021).

\subsection{Research design and sampling method}

A selection of 100 companies listed on the 2009-2018 Pakistan Stock Exchange for the oil and gas, textile, pharmaceutical, chemical, mining, sugar, fertilizer, cement, automotive, tobacco, power generation, food processing, footwear, and steel manufacturing sectors was systematically selected from this study. When deciding on the survey, companies that did not document activities mainly during the time of analysis in their annual CSR reports were excluded from the sample size of 100 firms. Similarly, from companies that were de-listed from the PSX and during study times, but where evidence was not adequate, the sample size was also excluded. Companies registered with the Pakistan Stock Exchange prior to 2009 and with a current share capital of Rs.100 million have been included in the sample size since their financial statements are continuously issued by large companies.

The inspected companies should also not include banks or commercial banks, such as lending firms, insurance firms, mutual fund shares, investment corporations, and investment mediators. Finally, it was considered fitting to select 58 firms from the manufacturing sectors listed on the PSX as a sample, on the ground that firms belonging to the manufacturing sector had a CSR operation greater than that of firms from other sectors. Second, manufacturing businesses have a greater degree of openness to environmental, development, and welfare activities relative to other sectors (Haniffa et al., 2005). Pakistan's manufacturers actively engage in CSR activities, have substantial CSR disclosures, and publish their sustainability reports due to its high share value and unused reserves (Ehsan et al., 2018). Finally, Pakistan's manufacturing industries contribute even more exports to global growth and to international perceptions; CSR activities, such companies, follow CSR activities (WBG, 2016).

In terms of their scale, purpose, importance, and the opinions of executives and investors, the activities of the CSR firm in Pakistan vary. The participation of giant national firms in CSR operations in Pakistan is more comparable to that of small and medium-sized enterprises (SMEs); the discovery of gas and oil, oil refineries, fertilizers, chemicals, pharmaceuticals, energy, cement, and other manufacturing firms, for example, follows a successful and well-planned CSR programmed. To comply with the guiding principles of the SECP and GRI, these companies frequently broadcast their sustainability reports. These sectors play a key role in the social welfare programmed in Pakistan, such as developing health facilities, encouraging technical, vocational, and research-based education, building infrastructure, alleviating poverty, helping orphans, and supporting the recovery of persons pretentious by natural tragedies (Prieto et al., 2006).

\subsection{CSR Scores}

It is possible to calculate the disclosure of CSR information in different ways, such as through internet sources, print media reports, and through annual reports published or an online version on company websites. For this study, the company's financial reports were considered adequate to assess the disclosure of CSR details, as the annual report was the primary means of disseminating information about CSR operations to stakeholders, Cown et al. (1987). As Deegan and Rankin (1997) argued, when making their decisions, many annual monitoring consumer organizations found the company's deliberate disclosures regarding environmental issues. Belal (2000) claimed that the most relevant source for disseminating company data is the company's published annual reports. The adoption of the company's financial results as a way of gathering data is also like other former scholars, Guthrie, and Parker (1990).

The system of CSR score quality analysis is used for measurement; the primary and secondary data of the organization is divided into categories based on company management rules (Talebnia et al (2013). Guthrie and Parker (1990) consider the form of content analysis to be very popular and widely 
recognized in the field of accounting of corporate social responsibility reporting. The material analytical techniques used for CSR reports in previous studies include multiple analysis units, such as word count, Deegan, and Gordon (1996), term count, Hackston, and Milne (1996). For this reason, to decide on categories-to-categories content units, we follow the classifications and items from the most important content analysis section (Nazir, 2011). Approximately 40 disclosure items form the Data Tool for Corporate Social Responsibility and cover seven main categories of CSR reporting, i.e. (contribution to the field of education and healthcare, the functioning of natural disasters, employee actions, environmental concerns, and declaration of product/service). To ensure that all the things listed in each major category are not ambiguous or mutually exclusive, a due effort was made.

\subsection{Measurement of CSR Disclosure Index}

The researchers conducted efforts to collect CSR data with due care to ensure the reliability of coding. In this study, tool item coding is performed as "1" if a specific item is reported for a specific period in the company's financial report and if it is not disclosed in the annual report, then coded as "0". If it is not disclosed in the annual report. For example, if a CSR item involving a donation from a company to the hospitals for cancer means of preventive medicine or eradication is reported in the financial report, it is coded "1" in the corresponding code column and "0" otherwise. To assess the final ranking of the group, the scores of all products in the major categories are then combined. Therefore, the CSR reporting model considers the accumulated results of the company's statements as follows.

$$
\mathrm{CSRDI}=\Sigma \mathrm{DI} 40 / \mathrm{NJ},
$$

Where DI is equal to " 1 " if the item DI is reported and otherwise " 0 ", $N J$ is the maximum number of items for $\mathrm{j}_{\mathrm{th}}$ firms and $\mathrm{NJ} \leq 40$.

To compute a percentage of the scores of the firm, the summation of each item's score is done, and this summation is divided by the maximum score. The product is then multiplied by 100 . In this process, the maximum amount of possible disclosure is 40 items. Hence, for example, if a firm out of the 40 items does not disclose a single item, the independent variable score will be 0 percent. Likewise, if a firm discloses only 20 items out of the total items, the firm's score for the independent variable will be $50 \%$.

\subsection{Measurement of the Share Price Crash Risk}

The stock price crash Risk (dependent variable), as defined by Kim et al. (2014), is a conditional skewness in the distribution of yield, which is measured accordingly. First, the firm, individual negative uncertain lopsidedness (NCSKEWj,t) of the return distribution about the $j_{\text {th }}$ firm during a particular financial year, $t$ is calculated using the equation (1), the greater the value of weekly negative conditional skewness shows the greater stock price crash risk.

$$
\left.N C S K E W=-\mid n(n-1)^{\frac{3}{2}} \sum \mathbb{U} \frac{w_{j, t}^{3}}{(n-1)(n-2)\left(\sum W_{j, t}^{2} \mathbb{I}\right)}\right) \frac{3}{2} \mid
$$

Here: " $n$ " means the total number of trading weeks in a year $\dot{t}$ and " $w$ " is a weekly yield of the firm $\mathrm{j}_{\mathrm{th}}$ in year $\mathrm{t}$. Calculated as Return $=\log (\mathrm{Pt} / \mathrm{Pt}-1)$

The $2^{\text {nd }}$ measure of the crash risk is down-to-up volatility (DUVOL) which is used to calculate the down-to-up volatility for probable crashes. Each firm's weekly stock yield is classified into two different categories, i.e., up to weekly stock yield when the specific firm's weekly stock yield is above the annual average weekly stock yield and down-weekly yield when the specific firm's weekly stock yield is below the annual average weekly stock yield. Since DUVOL does not involve the third moment (skewness) so it is not affected by extreme values of weekly stock yield. It is calculated through equation (2). As stated in Chen et al. (2001) and Kim et al. (2014), the higher value of DUVOL indicates the greater crash risk; 


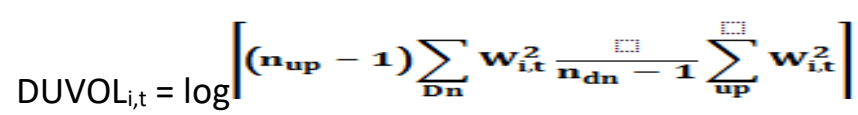

Here " ${ }_{u p}$ " means the total number of up weeks in year $\mathrm{t}, ~ "{ }{ }_{d n}$ " is the total number of down weeks in year $t, \Sigma_{D n} \mathbf{w}_{\mathbf{i . t}}^{2}$, means the total amount of weekly yield during the down weeks of firm $j_{\text {th }}$ in year $t$, and ${ }_{i=1}^{z}$, is the total amount of the weekly yield during the up weeks of firm $j_{\text {th }}$ in year $t$.

Table 1 Variable Description

\begin{tabular}{|l|l|l|}
\hline Variable & Symbol & Formula / Description \\
\hline $\begin{array}{l}\text { Share Price Crash Risk } \\
\text { (SPCR) }\end{array}$ & NSCKEWt+1 & Negation skewness of the firm-specific weekly yields over t + 1 years \\
\cline { 2 - 3 } & DUVOLt+1 & $\begin{array}{l}\text { Log of the ratio of the standard deviations of the down-week to up-week } \\
\text { of the firm-specific weekly returns over t + 1 years }\end{array}$ \\
\hline CSR & CSR,t & CSR reports index value \\
\hline $\begin{array}{l}\text { Corporate Governance } \\
\text { quality }\end{array}$ & CG & $\begin{array}{l}\text { Board size, ownership structure, Independent directors, and executive } \\
\text { directors }\end{array}$ \\
\hline Board Size & Bsize & Total number of directors on the board of directors of a firm \\
\hline $\begin{array}{l}\text { Ownership } \\
\text { concentration }\end{array}$ & OWC & Shareholding \% of the top 10 shareholders \\
\hline Independent Directors & Indp Directors & $\%$ of independent directors of total directors on the board of a firm \\
\hline Executive Directors & Exe directors & $\%$ of the executive directors of total directors on the board of a firm \\
\hline Firm Size & Size & Natural log of the firm's total assets \\
\hline $\begin{array}{l}\text { Rate of Return on } \\
\text { Assets }\end{array}$ & ROA & Net profit divided by total assets of the firm \\
\hline Return on Equity & ROE & Operating profit divided by shareholders' equity \\
\hline
\end{tabular}

In our study, the possible endogenous link between CSR and crash risk is a concern. When unnoticed firm-specific factors affect both CSR and crash risk, endogeneity may occur due to unnoticed heterogeneity. We have controls for variables that influence both CSR and crashing risk.

\section{Results and Discussion}

The descriptive results presented in Table 2 indicate that the average value of NCSKEW and DUVOL is less than $0(-.193986)$ and $(-.3154)$, and the standard deviation is $1.3047,1.1336$, respectively, in other words, there is a significant difference between companies in terms of the magnitude of the risk of a share price collapse. The average shareholding level of the top 10 investors is 67.42 , while the normal variation of ownership intensity is 20.26 , indicating a substantial difference between the companies included in this research report in the shareholding trend. The average and standard variance of the direct proportion of board independence to the board of directors is 2.09 and 16.8559 , as well as the standard deviations of the direct proportion of board management to the executive board, are 1.74 and 10.956, showing that the board composition of independent and executive directors varies greatly from that of firms. The total return on equity valuation shows that, on average, the sample companies gain 23.69 times more on each equity investment. Descriptive figures show that the company's profitability differs considerably.

The findings in table 3 show a correlation between all variables included in our study. In line with prior studies by Andreou et al. (2016) and Callen \& Fang, the crash risk measures (NCSKEWj and DUVOLj) have a negative correlation with CSR (2015). With the prospect of a stock price crash, all governance variables have a positive and negative relationship. With a coefficient of $-0,157$, the proportion of executive directors to the board of directors is negative and significantly associated with the NCSKEW and with a coefficient of $-0,178$, and also significantly and negatively correlated with the DUVOL. For both crash risk steps, the concentration of ownership (the shareholding percentage of the top 10 shareholders) has an ambitious but immaterial connection. There is a substantial negative correlation between the return on assets and DUVOL $(-0.129)$, and the negative correlation with NCSKEW is negligible. With the possibility of a stock market collapse, the ROE has an adverse relationship. 
Does Quality of Corporate Governance Moderate the Relationship between Corporate Social Responsibility and Stock Price Crash Exposure

Table 2 Overview of Basic Statistics

\begin{tabular}{|l|c|c|c|c|}
\hline Variables & Minimum & Maximum & Mean & Std. Deviation \\
\hline NCSKEW & -7.0039 & 6.1699 & -.193986 & 1.3047 \\
\hline DUVOL & -4.3492 & 3.8442 & -.315394 & 1.1336 \\
\hline CSR_Index Values & 7.50 & 57.50 & 41.5643 & 10.476 \\
\hline Board Size & 6.00 & 14.00 & 8.9457 & 1.7328 \\
\hline \% of Independent Directors & .0000 & 80.0000 & 2.0972 & 16.8559 \\
\hline \% of Executive Directors & .0000 & 85.7143 & 1.7435 & 10.9563 \\
\hline Ownership Concentration & 17.76 & 97.62 & 67.4231 & 20.2573 \\
\hline Firm Size & 2.9889 & 7.6912 & 4.4603 & .6249 \\
\hline Return on equity & -131.40 & 270.16 & 23.6940 & 38.1397 \\
\hline
\end{tabular}

Table 3 Correlation Matrix

\begin{tabular}{|l|c|c|c|c|c|c|c|}
\hline Variables & NCSKEW & DUVOL & CSR & BSize & In.Director & Ex. Director & OWC \\
\hline DUVOL & 0.672 & 1 & & & & & \\
\hline CSR & -0.106 & -0.009 & 1 & & & & \\
\hline Board Size & 0.063 & 0.087 & 0.120 & 1 & & & \\
\hline Indep. Directors & 0.157 & 0.102 & 0.001 & .0176 & 1 & & 1 \\
\hline Executive Directors & -0.157 & -0.178 & 0.107 & -.0118 & -.235 & & \\
\hline OWC & 0.061 & 0.046 & 0.190 & 0.148 & 0.008 & 0.224 & 1 \\
\hline ROE & -0.067 & $0-.066$ & 0.002 & -0.088 & 0.004 & 0.320 & 0.21 \\
\hline
\end{tabular}

In the background of the company's stock price crash risk and its CSR knowledge disclosure, the pooled OLS models are used to examine the relationship. The findings of the first regression model as appended in Table 4 below indicate that the CSR of the companies has a major adverse effect on the 1st crash danger proxy (NCSKEW) by holding the influence of all other interpreter's constant. These findings indicate that the company's crash risk (NCSKEW) would decrease if the company's CSR increases as findings. Therefore, economically and statistically, the impact of CSR on the crash risk of companies is. Overall findings indicate that comparatively low stock price crash risk is suffered by communally accountable businesses. The findings support the connotation that it is less anticipated for publicly accountable corporations to store malicious bulletins and maintain a high degree of accountability in releasing the information, resulting in less likelihood of a share price crash. The findings show that the standard deviation in the amount of the company's corporate social responsibility index decreases statistically substantially in the 1st proxy (NCSKEW); however, the effect of CSR on the 2nd crash risk measure (DUVOL) becomes negligible. The size of the board and the restructuring of ownership have an additive but negligible effect on all crash risk steps. The independent directors have a large additive effect on the probability of the crash, suggesting that a normal increase in the proportionate variance of the independent director would increase the NCSKEW of 0.088 units; however, the impact on the 2 nd proxy (DUVOL) becomes negligible. The executive directors have a major negative effect on the company's stock price crash risk. The regression result indicates that one normal increase in the proportionate variance of the executive directors would result in a decrease of 0.155 units in the 1st proxy (NCSKEW) and a decrease of 0.186 units in the 2 nd proxy (DUVOL) of the company's crash risk.

Table 4 Pooled OLS Results of NCSKEW \& DUVOL

\begin{tabular}{|l|c|c|c|c|}
\hline \multirow{2}{*}{ (Constant) } & \multicolumn{2}{|c|}{ NCSKEW } & \multicolumn{2}{c|}{ DUVOL } \\
\cline { 2 - 4 } & B & Sig. & B & Sig. \\
\hline CSR & -0.188 & 0.680 & -0.802 & 0.045 \\
\hline BOSize & -0.015 & 0.030 & -0.001 & 0.814 \\
\hline BI & 0.025 & 0.581 & 0.052 & 0.185 \\
\hline ED & 0.088 & 0.047 & 0.041 & 0.294 \\
\hline OWC & -0.155 & 0.041 & -0.186 & 0.005 \\
\hline Adj-R2 & 0.007 & 0.064 & 0.004 & 0.172 \\
\hline
\end{tabular}

To check the moderating impact of the norm of corporate governance between CSR and the stock price crash risk of the business, we used a random-effect model. The findings provided in the table indicate that the executive directors' interaction effect significantly confirms the negative correlation amid the company's social responsibility and both proxies of the danger of the share price crash and 
the interaction term of the independent directors and ownership concentration reinforces the positive correlation amid CSR

Table 5 Moderating Results

\begin{tabular}{|l|c|c|c|c|}
\hline \multirow{2}{*}{} & \multicolumn{2}{|c|}{ NCSKEW } & \multicolumn{2}{c|}{ DUVOL } \\
\cline { 2 - 4 } & B & Sig. & B & Sig. \\
\hline Constant & 1.390 & 0.070 & -0.276 & 0.267 \\
\hline CSR & -0.490 & 0.020 & -0.001 & 0.845 \\
\hline Board Size & 0.038 & 0.102 & 0.056 & 0.367 \\
\hline IBD & 0.158 & 0.026 & 0.062 & 0.321 \\
\hline Executive Directors & -0.179 & 0.014 & -0.198 & 0.002 \\
\hline OWC & 0.146 & 0.043 & 0.089 & 0.157 \\
\hline Size & 0.109 & 0.345 & -0.068 & 0.498 \\
\hline ROA & -0.005 & 0.591 & -0.017 & 0.046 \\
\hline ROE & 0.206 & 0.740 & 0.002 & 0.434 \\
\hline Year\&Ind & YES & & YES & \\
\hline Adj-R2 & 18.62 & & 14.82 & \\
\hline
\end{tabular}

As the literature suggests that crash risk is also mitigated through other variables than the corporate social responsibility information disclosures of the firm; therefore, we also investigated the relationship of crash risk with some control variables such as the firm size, ROA, and ROE. However, contrary to the prior studies, the result of this study reveals that the magnitude of the firm has an additive but insignificant effect on the crash risk (NCSKEW; DUVOL). The ROA has a negative influence on NCSKEW and DUVOL; it means that increase in ROA will result in a decrease in the stock crash risk.

\section{Conclusion}

In this paper, we examine whether the corporate governance standard moderates the relationship between CSR and the possibility of a stock price crash on the Pakistan stock exchange for listed companies during 2009-2018. In general, socially responsible companies are expected to be transparent with a low level of malicious bulletin stockpile activities in disclosing financial information, resulting in a lower likelihood of share price crash risk. In this case, it can be concluded that the company's CSR operations are negatively related to the risk of a crash in the share price. On the contrary, if the CSR actions of the company are mere to conceal their wrongdoings and to sidetrack the attention of shareholders, then the CSR may increase the risk of the company's share price collapse. Results obtained from pooled OLS show that the possibility of a stock price collapse is mitigated by the activities of CSR. The results of this study maintain the notion that the manager has a lower propensity to cover the bad news of the business in corporate culture with a strong alignment with the CSR operations, resulting in a low risk of a crash in share price. Our findings are in line with the available literature and the results of a survey conducted by Kim et al. (2014). The findings of this study are probably the result of the ethical approach of the sample companies to their interest in all CSR domains. Businesses aim to comply with the ethics requirement in their financial statements to meet society's expectations so that corporations offer high-quality and reliable information to stakeholders (whether good or bad news). Therefore, at the firm level, the accumulation of malicious bulletins is minimized, resulting in a lower likelihood of share price risk.

In addition, the findings of corporate governance experience suggest that board size has a beneficial relationship with the risk of stock prices, albeit not in line with previous research results (Andreu et al., 2016). While other quality attributes of corporate governance, such as ownership concentration, explain 9 percent to 14.7 percent of the one standard deviation of the crash risk by the proportionate of independent and executive directors to the company board, which suggests that the influence of these attributes on the crash risk of the company is not statistically exceptional and results are biocompatible. Analyzing whether CG moderates the relationship between CSR and the probability of stock price collapse is also important and ranges from 11.20 percent to 13.80 percent was the moderation impact of the quality characteristics of Corporate Governance. Regression findings also show that the association is weakened in the sense of corporate social responsibility and the crash risk, 
considering the proportionate of the board's independent directors and the ownership concentration (shareholding proportionate of the top 10 shareholders) as moderating variables, whereas the proportionate of the board's executive directors are weakened as a moderating variable powder.

This study's third hypothesis also proves that. According to Kim et al., large firms with high ROA are more vulnerable to crash risk (2014). We may infer that, from Pakistan's perspective, the high ROA mitigates the company's stock price crash risk. It is suggested that the relevant capital market authorities should be actively involved in promoting the social culture and trends of companies, with a view to business growth. Before making their investment decision, investors should not only embrace but evaluate the CSR data of the company as a trigger that disrupts the stock price crash. This research study has major theoretical and practical significance, being Pakistan's first in the field of stock price crash risk, but there is a need to increase the sample size to increase the results' trustworthiness and generalization. Secondly, to check the impact of CSR on the likelihood of a stock price crash for companies belonging to various sectors of the industry, a comparative study based on the classification of the industry in Pakistan should be carried out. Third, it is important to examine empirically the impact of other influential variables, such as board diversity, the reputation of the audit firms involved, the type of ownership, and institutional shareholding, both within and outside.

\section{References}

1. Abbas, S., Nguyen, V.C., Yanfu, Z.Y., Nguyen, H.T. (2020). The Impact of China Exchange Rate Policy on its Trading Partners: Evidence Based on the GVAR Model. Journal of Asian Finance, Economics and Business, 7(8), 131-141. DOI: https://doi/org/10.13106/jafeb.2020.vol7.no8.131. doi: 10.13106/jafeb.2020.vol7.no8.131

2. Alkurdi, A., Hussainey, K., Tahat, Y., \& Aladwan. (2019). The impact of corporate governance on risk disclosure: Jordanian evidence. Academy of Accounting and Financial Studies Journal, 23 (1), 1-16.

3. An, H., and T. Zhang, (2013), Stock price synchronicity, crash risk, and institutional investors, Journal of Corporate Finance 21, 1-15 and Quantitative Analysis, 50 (1-2), 169-195.

https://doi.org/10.2469/dig.v43.n3.6

4. Andreou, P. C., Antoniou, C., Horton, J., and Louca, C. (2016), Corporate Governance and Firmspecific Stock Price Crashes. European Financial Management, 22(5): 916-956, https://doi.org/10.1111/eufm.12084

5. Armstrong, C. S., Balakrishnan, K., Cohen, D. (2012). Corporate governance and the information environment: Evidence from state anti-takeover laws. J. Account. Econ. 53(1), 185-204. DOI: 10.1016/j.jacceco.2011.06.005

6. Bae, K. H., Lim, C., \& Wei, K. J. (2006). Corporate governance and conditional skewness in the world's stock markets. The Journal of Business, 79(6), 2999-3028.

7. Baker, S. R., N. Bloom, and S. J. Davis, (2016), Measuring economic policy uncertainty, The Quarterly Journal of Economics 131, 1593-1636. https://doi.org/10.1093/qje/qjw024

8. Ball, R., Jayaraman, S., \& Shivakumar, L. (2009). The complementary roles of audited financial reporting and voluntary disclosure. DOI: 10.2139/ssrn.1489975

9. Belal, A. (2000), Environmental Reporting in Developing Countries: Empirical Evidence from Bangladesh. Eco-Manag. Audit. 7, 114-121.

https://doi.org/10.1002/1099-0925(200009)7:3<114::AID-EMA131>3.0.CO;2-E

10.Bhana N., (1997). The effect of industrial strikes on the value of shares listed on the Johannesburg Stock Exchange. Investment Analysts Journal, 26, 43-49.

https://doi.org/10.1080/10293523.1997.11082366

11.Blair, M. M. (1995). Rethinking assumptions behind corporate governance. Challenge, 38(6), 12-17. https://doi.org/10.1080/05775132.1995.11471861

12.Bogdan, R., \& Taylor, S. J. (1975). Introduction to qualitative research methods: A phenomenological pproach to the social sciences. New York: John Wiley \& Sons, Inc. https://doi.org/10.1080/05775132.1995.11471861 
13.Bradley Jr, R. L. (2009). Corporate social responsibility and energy.Culture and civilization, 1, 181197. DOI https://doi.org/10.18551/rjoas.2017-08.23

14.Brammer S. J., and Pavelin S., (2006). Corporate Reputation and Social Performance: The Importance of Fit. Journal of Management Studies, 43, 3, 435-455.https://doi.org/10.1111/j.14676486.2006.00597.x

15.Callen, J. L., and X. Fang, (2015), Religion and stock price crash risk, Journal of Financial and Quantitative Analysis 50, 169-195. DOI: https://doi.org/10.1017/S0022109015000046

16.Chih, H.H., Miao, W.C. and Chuang, Y.C. (2014), "Is corporate social responsibility a double-edged sword? Evidence from fortune global 500 companies", Journal of Management, 31(1), 1-19. DOI: 10.14456/ITJEMAST.2020.257

17.Cho, S. Y., Lee, C., dan Pfeiffer, R. J. (2013), Corporate social responsibility performance and information asymmetry. Journal of Accounting and Public Policy, 32 (1), 71-83. DOI: 10.1007/s10997-015-9309-1

18.Clarkson M., (1995). A stakeholder framework for analyzing and evaluating corporate social performance.Academy of Management Review, 20, 92-117. https://doi.org/10.2307/258888

19.Cornell, B.; Shapiro, A.C., (1987) Corporate Stakeholders and Corporate Finance. Finance. Manag., 16, 5-14.corporate governance characteristics in Malaysian public listed companies. DOI: $10.1007 / \mathrm{s} 10551-013-1887-8$

20.Dang, C.; Li, Z.F.; Yang, C. (2018) Measuring firm size in empirical corporate finance. J. Bank finance. DOI: 10.1016/j.jbankfin.2017.09.006

21.Dao, L.K.O. Loc, H.H., Nguyen, V.C., Hang, L.T.T., Do, T.T. (2021). Factors Affecting the Choice of Banks: Do Bank's Interest Rate, Employee Image and Brand Matter? Journal of Asian Finance, Economics and Business, 8(1), 457-470. https://doi.org/10.13106/jafeb.2021.vol8.no1.457.

22.Deegan, C., \& Unerman, J. (2011). Financial accounting theory (2nd Ed.). London: McGraw-Hill.

23.Deegan, C.; Gordon, B., (1996) A Study of the Environmental Disclosure Policies of Australian Corporation. Account. Bus. Res., 26, 187-199. https://doi.org/10.1080/00014788.1996.9729510

24.Deegan, C.; Rankin, M. (1997) The Materiality of Environmental Information for Users of Annual Reports. Account. Audit. Account. J., 10, 562-583. DOI: 10.12691/jfa-5-1-4

25.Dhaliwal, D. S., Li, O. Z., Tsang, A., et al. (2011). Voluntary nonfinancial disclosure and the cost of equity capital: The initiation of corporate social responsibility reporting. Accounting Review, 86(1). https://doi.org/10.2308/accr.00000005

26.Donaldson, L. (1990). The ethereal hand: Organizational economics and management theory. Academy of Management Review, 15(3), 369-381. https://doi.org/10.2307/258013

27.Donaldson, T., \& Preston, L.E. (1995). The Stakeholder theory of the corporation: Concepts, evidence, and implication. Academy of Management Review, 20 (1), 65-91. https://doi.org/10.2307/258887

28.Easterby-Smith, M., Thorpe, R., \& Jackson, P. R. (2009). Management research (3rd Ed.). London: Sage Publications Ltd.

29.Ehsan, S., Abbas, Q., \& Nawaz, A. (2018). An inquiry into the Relationship between Earnings' Management, Corporate Social Responsibility, and Corporate Governance. Abasyn University Journal of Social Sciences, 11(1). https://doi.org/10.13106/jafeb.2020.vol7.no3.29

30.El Ghoul, S., Guedhami, O., Kwok, C. C., \& Mishra, D. R. (2011). Does corporate social responsibility affect the cost of capital? Journal of Banking \& Finance, 35(9), 2388-2406. https://doi.org/10.1177/0007650316677936

31.Freeman, I., \& Hasnaoui, A. (2011). The meaning of corporate social responsibility: The vision of four nations. Journal of Business Ethics, 100(3), 419-443. DOI: 10.1007/s10551-010-0688-6

32.Friedman, M. (1970) The Social Responsibility of Business is to Increase Its Profits. New York Times Magazine. DOI: 10.1007/978-3-540-70818-6_14

33.Goss, Allen, and Gordon S. Roberts. 2011. The impact of corporate social responsibility on the cost of bank loans. Journal of Banking \& Finance 35: 1794-810.

34.Graham, J. R., Harvey, C. R., \& Rajgopal, S. (2005). The economic implications of corporate financial reporting. Journal of Accounting \& Economics, 40 (1-3), 3-73. DOI: 10.1016/j.jacceco.2005.01.002 
35.Guthrie, J.; Parker, L. (1990) Corporate Social Disclosure Practice: A Comparative International Analysis. Adv. Public Interest Account., 3, 159-175. DOI: 10.14453/aabfj.v10i1.3

36. Hackston, D.; Milne, M.J., (1996) Some Determinants of Social and Environmental Disclosures in New Zealand Companies. Account. Audit. Account. J. 9, 77-108. http://dx.doi.org/10.1108/09513579610109987

37.Haniffa, R.M.; Cooke, T.E., (2005). The impact of culture and governance on corporate social reporting. J. Account. DOI: 10.1016/j.jaccpubpol.2005.06.001

38.Hategan, C.D.; Sirghi, N.; Curea-Pitorac, R.I.; Hategan, V.P., (2018) Doing Well or Doing Good: The Relationship between Corporate Social Responsibility and Profit in Romanian Companies. Sustainability, 10, 1041. https://doi.org/10.3390/su10041041

39. Healy, P.M., Hutton, A.P., \& Palepu, K.G. (1999). Stock performance and Interm edition change surrounding sustained increases in disclosure. Contemporary accounting research, 16 (3), 485-520. https://doi.org/10.1111/j.1911-3846.1999.tb00592.x

40.Heinle, M. S., Smith, K. C., \& Verrecchia, R. E. (2018). Risk-Factor Disclosure and Asset Prices. The Accounting Review, 93(2), 191-208.

41.Hemingway, C.A., and Maclagan, P.W. (2004). Managers' personal values as drivers of corporate social responsibility", Journal of Business Ethics, 50(1), 33-44 DOI 10.1007/s10551-005-0132-5

42.Hoang, T. C., Abeysekera, I., \& Ma, S. (2018). Board diversity and corporate social disclosure: Evidence from Vietnam. Journal of Business Ethics, 151(3), 833-852. https://doi.org/10.31106/jema.v16i2.2700

43.Hoi, C. K., Wu, Q., \& Zhang, H. (2013). Is corporate social responsibility (CSR) associated with tax avoidance? Evidence from irresponsible CSR activities. The Accounting Review, 88(6), 2025-2059. DOI: $10.2308 /$ accr-50544

44.Hong, H., Stein, J.C., (2003). Differences of opinions, short-sales constraints, and market crashes. Rev. Financial Stud. 16, 487-525. DOI: 10.1093/rfs/hhg006

45.Hou, J., \& Reber, B. H. (2011). Dimensions of disclosures: Corporate social responsibility (CSR) reporting by media companies. Public Relations Review, 37(2), 166-168. https://doi.org/10.1080/23736992.2018.1440558

46. Huang, C., \& Kung, F. (2010). Drivers of environmental disclosure and stakeholder expectation: Evidence from Taiwan. Journal of Business Ethics, 96(3), 435-451. DOI: 10.1007/s10551-010-04763

47.Hutton, A., Marcus, A., Tehranian, H., (2009). Opaque financial reports, R2, and crash risk. Journal of Financial Economics 94, 67-86. DOI: 10.1016/j.jfineco.2008.10.003

48.Jin, L., \& Myers, S. C. (2006). R2 around the world: New theory and new tests. Journal of Financial Economics, 79(2), 257-292. https://doi.org/10.1016/j.jfineco.2004.11.003

49.Kim, J.-B., L. Li, L. Y. Lu, and Y. Yu, (2016), Financial statement comparability and expected crash risk, Journal of Accounting and Economics 61, 294-312.

https://doi.org/10.1016/j.jacceco.2015.12.003

50.Kim, J.B., Li, Y., Zhang, L., (2011). CFO vs. CEO: equity incentives and crashes. Journal of Financial Economics 101(3), 713-730. https://doi.org/10.1016/j.jfineco.2011.03.013

51.Kim, J.B., Zhang, L., (2013). Does accounting conservatism reduce stock price crash risk? Firm-level evidence. Contemporary Accounting Research, forthcoming. https://doi.org/10.1111/19113846.12112

52.Kim, Y., Li, H., \& Li, S. (2014). Corporate social responsibility and stock price crash risk. Journal of Banking \& Finance, 43, 1-13. https://doi.org/10.1016/j.jbankfin.2014.02.013

53.Kim, Y., Park, M.S., Wier, B., (2012). Is earnings quality associated with corporate social responsibility? The Accounting Review 8 (3), 761-796. https://doi.org/10.2308/accr-10209

54.Kim, Y., Statman, M., (2012)., Do Corporations Invest Enough in Environmental Responsibility? Journal of Business Ethics, 105 (1), 115-129, DOI: 10.1007/s10551-011-0954-2

55.Kim, Yongtae, Haidan Li, and Siqi Li., (2014) "Corporate Social Responsibility and Stock Price Crash Risk." Journal of Banking \& Finance 43: 1-13. DOI: 10.1016/j.jbankfin.2014.02.013 
56.Laan Smith, J., Adhikari, A., \& Tondkar, R. H. (2005). Exploring differences in social disclosures internationally: A stakeholder perspective. Journal of Accounting and Public Policy, 24(2), 123-151. DOI: 10.1016/j.jaccpubpol.2004.12.007

57.Lam, S. S., H. Zhang, and W. Zhang, (2018), Does policy instability matter for international equity markets?, International Review of Finance, https://doi.org/10. 1111/irfi.12222. DOI: 10.1111/irfi.12277

58.Li, X. M., (2017), New evidence on economic policy uncertainty and equity premium, Pacific-Basin Finance Journal 46, 41-56. DOI: 10.1016/j.pacfin.2017.08.005

59.Li, X. R., Wang, S. S., \& Wang, X. (2017). Trust and stock price crash risk: Evidence from China. Journal of Banking \& Finance, 76, 74-91. DOI: 10.1016/j.jbankfin.2016.12.003

60.Li, Y., Gong, M., Zhang, X.-Y., \& Koh, L. (2018). The impact of environmental, social, and governance disclosure on firm value: The role of CEO power. The British Accounting Review, 50 (1), 60-75. https://doi.org/10.1016/j.bar.2017.09.007

61.Lins, Karl V., Servaes, Henri and Tamayo, Ane (2017) Social capital, trust, and firm performance: the value of corporate social responsibility during the financial crisis. The Journal of Finance. 22-1082. https://doi.org/10.1111/jofi.12505

62.Lu, J., and Nakajima, K. (2014), "Corporate social responsibility and crash risk for Japanese firms", Research Review, 1-11.

63.Masulis, R. W., Wang, C., \& Xie, F. (2007). Corporate governance and acquirer returns. The journal of Finance, 62(4), 1851-1889. DOI: 10.2139/ssrn.697501

64.Matten. D., \& Crane, A. (2005). Corporate citizenship: Toward an extended theoretical conceptualization. Academy of Management Review, 30 (1), 166-179. https://doi.org/10.2307/20159101

65.McWilliams, A., Siegel, D.S., and Wright, P.M. (2006), "Corporate social responsibility: strategic implications", Journal of Management Studies, 43(1), 1-18. https://doi.org/10.1111/j.14676486.2006.00580.x

66. Muttakin, M. B., Khan, A., \& Subramaniam, N. (2015). Firm characteristics, board diversity, and corporate social responsibility: Evidence from Bangladesh. Pacific Accounting Review, 27 (3), 53372. DOI: 10.1108/CG-12-2018-0371

67.Nazir, S.M., (2011) Corporate Social Disclosure in Pakistan: A Case Study of Fertilizers Industry. J. Commerce2, 1-11.

68. Nguyen, V.C., Do, T.T. (2020). Impact of Exchange Rate Shocks, Inward FDI and Import on Export Performance - A Cointegration Analysis. Journal of Asian Finance, Economics and Business, 7(4), 163-171. https://doi.org/10.13106/jafeb.2020.vol7.no4.163

69.Ni, X., \& Zhu, W. (2016). Short-sales and stock price crash risk: Evidence from an emerging market. Economics Letters, 144, 22-24. DOI: 10.1016/j.econlet.2016.04.029

70.Piotroski, J.D.; Wong, T.J.; Zhang, T. (2015) Political Incentives to Suppress Negative Information: Evidence from China Listed Firms. J. Account. Res., 53, 405-459. DOI: 10.1111/1475-679X.12071

71.Preston, L.E.; O'Bannon, D.P. (1997) The Corporate Social-Financial Performance Relationship: A Typology and Analysis. Bus. Soc., 36, 419-429. DOI:10.1111/1475-679X.12071

72.Prieto-Carrón, M., Lund-Thomsen, P., Chan, A., Muro, A., \& Bhushan, C. (2006). Critical perspectives on CSR and development: what we know, what we don't know, and what we need to know. International affairs, 82(5), 977-987. DOI: 10.1111/j.1468-2346.2006.00581.x

73.Prior, D., Surroca, J., danTribó, J. A. (2008). Are socially responsible managers really ethical? Exploring the relationship between earnings management and corporate social responsibility. Corporate Governance: An International Review, 16 (3), 160-177. https://doi.org/10.1111/j.14678683.2008.00678.x

74.Roberts, R. W. (1992). Determinants of corporate social responsibility disclosure: An application of stakeholder theory. Accounting, Organizations and Society, 17 (6), 595-612.

https://doi.org/10.1016/0361-3682(92)90015-K 
75.Talebnia, Gh., Alikhani, R., and Maranjoori, M. (2013). Evaluating the Quantity and Nature of Disclosure of Environmental and Social Accounting Information in Iran. Journal of the accounting and auditing review 19 (69), 43-60. DOI: 10.22067/ijaaf.v2i1.66588

76.Westphal, J. D., \& Zajac, E. J. (1995). Who shall govern? CEO/board power, demographic similarity, and new director selection. Administrative science quarterly, 60-83. https://doi.org/10.5465/amj.2011.0590

77.Xie, B., Davidson III, W. N., \& DaDalt, P. J. (2003). Earnings management and corporate governance: the role of the board and the audit committee. Journal of Corporate Finance, 9(3), 295-316. DOI: 10.19030/jabr.v29i2.7646

78.Xu, N., X. Li, Q. Yuan, and K. C. Chan, (2014), Excess perks and stock price crash risk: evidence from China, Journal of Corporate Finance 25, 419-434. DOI: 10.1016/j.jcorpfin.2014.01.006 